\title{
EGEDI-KOVÁCS EMESE
}

\section{A BARLÁM-REGÉNY KÓDEXKÉPEI ÉS CÍMSORAI (COD. ATHON. IVIRON 463)"}

\begin{abstract}
A tanulmány az Athós-hegyi Iviron 463-as jelzetủ kétnyelvü (ógörög-ófrancia) bizánci kézirat különféle rétegeinek (ógörög főszöveg, miniatúrák, lapszélen szereplő ófrancia fordítás, ófrancia címsorok) összefüggéseit vizsgálja újabb megközelítésből, korábban nem vizsgált szempontok bevonásával: a miniatúrák és az ófrancia szövegben szereplő piros tintával kiemelt címsorok közötti kapcsolat feltárásával. A tanulmány a Barlám-regény görög változatait megőrző kódexek - ivironi kézirat szempontjából fontos - magyarázó címeit is áttekinti, a kéziratok közötti közös elemeket vizsgálja. Az elemzés az ivironi kódex készítésének körülményeivel kapcsolatban újabb fontos összefüggésekre világít rá.

Kulcsszavak: Cod. Athon. Iviron 463, Barlám és Jozafát, szentélet, Vat. Gr. 394, BnF Gr. 1128, King's College Library Cod. 45, miniatúrák, magyarázó címek
\end{abstract}

Az Athós-hegyi Iviron 463-as jelzetü kézirat régóta kiemelt tárgya a művészettörténeti kutatásoknak. ${ }^{1}$ A luxuskivitelü bizánci kéziratot, amely a Barlám és Jozafát regény rövidített görög változatát őrizte meg, 79 páratlan szépségü, aprólékosan megmunkált miniatúra díszíti. A kézirat a XI. század végén Konstantinápolyban készült, ${ }^{2}$ másolója és egyben illusztrátora bizonyos Kónstantinos nevü szerzetes lehetett. ${ }^{3}$ A kézirat további érdekessége, hogy lapszélein ismeretlen szerzőtől származó ófrancia kézírás szerepel, amely nem más, mint a kódex görög szövegének hủ fordítása. Az egyedülálló ófrancia nyelvemlékről és szövegkritikai kiadásának előkészületeiről megelőző tanulmányaimban részletesen beszámoltam. ${ }^{4}$ A kódex megrongálódása miatt töredékes állapotban

* A tanulmány az NKFIH NN 124539 számú „Társadalmi kontextus a szövegkritika tükrében: Bizáncon innen és túl" című pályázat, a Magyar Tudományos Akadémia Bolyai János Kutatási Ösztöndíja és az Információs és Technológiai Minisztérium ÚNKP-19-4 kódszámú Új Nemzeti Kiválóság Programjának szakmai támogatásával készült.

${ }^{1}$ Az Athon. Iviron 463-as kézirat legújabb művészettörténeti kutatásairól lásd: C. J. Hilsdale: The Imperial Image at the End of Exile: The Byzantine Embroidered Silk in Genoa and the Treaty of Nymphaion (1261). DOP 64 (2010) 151-199, passim; M. Toumpouri: Le cas du Hagion Oros, Monè Ibèron, 463. In: Barlaam und Josaphat. Neue Perspektiven auf ein europäisches Phänomen. Eds. M. Meyer - C. Cordoni. Berlin - München - Boston 2015. 389-416; C. J. Hilsdale: Worldliness in Byzantium and Beyond: Reassessing the Visual Networks of the Greek Barlaam and Ioasaph. The Medieval Globe 3/2 (2017) 60-63, 80-83; M. Toumpouri: Barlaam and Ioasaph. In: A Companion to Byzantine Illustrated Manuscripts. Ed V. Tsamakda. Leiden - Boston 2017. 149-168.

2 A kódex datálásával kapcsolatban korábban számos elmélet látott napvilágot, Francesco D’Aiuto azonban legújabban meggyőző érvekkel bizonyította, hogy a kódex a XI. század végén (1075 körül) készülhetett a konstantinápolyi Lophadion kolostorban. F. D’Aiuto: Su alcuni copisti di codici miniati mediobizantini. Byzantion 67 (1997) 5-59.

${ }^{3}$ D'Aiuto: i. m. (2. jegyz.) 27-29.

${ }^{4}$ E. Egedi-Kovács: La traduction française de la version grecque dite d'Iviron de Barlaam et Joasaph. À propos de l'édition critique en cours. In: Investigatio Fontium. Ed. L. Horváth. Budapest 2014. 83-94. http://byzantium.eotvos.elte.hu/wp-content/uploads/2016/07/Investigatio.pdf; E. Egedi-Kovács: Quelques 
ránk maradt ófrancia szöveg helyreállításához - amely egyetlen ismert ófrancia változattal sem egyezik - mindenekelőtt elengedhetetlen volt a kódex görög főszövegének átírása. Jóllehet a görög Barlám-regény különféle szövegváltozatai a Loeb Classical Library sorozatban megjelent kötetnek, ${ }^{5}$ és különösen a Robert Volk-féle kritikai kiadásnak köszönhetően mára jól ismertek, ${ }^{6}$ az ivironi kódexben szereplő szövegváltozat egyedi olvasatait korábban nem vizsgálták. Az Antik Tanulmányok 62. kötetében megjelent tanulmányomban a görög Barlám-regény ivironi változatának átírása és kollacionálása során megfigyelt filológiai jelenségeket, valamint a szöveg egyedi olvasatait ismertettem, ${ }^{7}$ és összevetettem azokat az ófrancia fordításban szereplő szöveghelyekkel. Mindezek alapján érdekes összefüggések mutatkoztak meg elsősorban a fordítás készítésének körülményeivel kapcsolatban. A vizsgálat során a következő megállapításokat tettem: egyfelől - a szakirodalom korábbi vélekedéseivel ellentétben - egyértelműen kijelenthetjük, hogy a francia fordító nem közvetlenül az ivironi kódex görög szövegét vette alapul a fordításhoz. Ha kizárólag ezzel a változattal dolgozott volna, a görög másolótól vétett hibáknak a francia változatban is szerepelniük kellene, márpedig ezeket a francia fordító egytől-egyig „javította”, vagy - ami inkább hihető - a fordítást a helyes változat alapján készítette. Különösen érdekesek azon szöveghelyek, ahol olyan szó is szerepel a fordításban, amelyet a görög írnok a másolás során kifelejtett. Ugyanakkor fontos azt is megjegyezni, hogy az ivironi kódex görög szövegének egyedi, más kéziratban nem szereplő olvasatai kivétel nélkül megjelennek az ófrancia fordításban is. Valószínűsíthető tehát, hogy a fordítás olyan szöveg alapján készült, amely egyúttal az ivironi kézirat görög szövegének mintája is lehetett. Feltételezésünk szerint létezett egy mára elveszett másolói példány, amelyet a görög írnok és a francia fordító egyaránt használhatott, ami magyarázattal szolgálhat a fent említett filológiai jelenségekre. Amennyiben e feltételezés helytálló, úgy az ófrancia fordítás készítésének körülményei és a szöveg datálásának

remarques sur la langue de la traduction française dite d'Iviron de Barlaam et Josaphat (ms. Athon. Iviron 463). In: Byzanz und das Abendland IV. Ed. E. Juhász. Budapest 2016. 135-141. http://byzantium.eotvos. elte.hu/wp-content/uploads/B_und_A_IV.pdf; Egedi-Kovács E.: A Barlám és Jozafát Athosz-hegyi ófrancia fordításának nyelvi jelenségei (cod. athon. Iviron No. 463). In: Klasszikus Ókor, Bizánc, Humanizmus. A XII. Magyar Ókortudományi Konferencia előadásaiból. Szerk. Mészáros T. Budapest 2017. 159-162. http:// byzantium.eotvos.elte.hu/wp-content/uploads/MOK_12.pdf; E. Egedi-Kovács: Un trésor inexploré entre Constantinople, le Mont Athos et le monde franc. Le manuscrit Athon. Iviron 463. In: Investigatio Fontium II. Eds. L. Horváth - E. Juhász. Budapest 2017. 89-164. http://byzantium.eotvos.elte.hu/wp-content/uploads/ Investigatio_II.pdf; Egedi-Kovács E.: A Barlám és Jozafát regény kétnyelvű változata. Az Iviron 463-as jelzetű (ógörög-ófrancia) kézirat. AntTan 62 (2018) 55-80; E. Egedi-Kovács: Prolégomènes à l'édition critique de la version grecque du manuscrit d'Iviron de Barlaam et Joasaph (cod. Athon. Iviron 463). ZRVI 55 (2018) 127-140; Egedi-Kovács E.: Prolegomena az Iviron 463-as jelzetủ kézirat görög szövegének kritikai kiadásához. AntTan 62 (2019) 85-95; Egedi-Kovács E.: Interpretatio byzantino-gallica (Barlaam et Ioasaf, cod. Athon. Iviron 463). AntTan 63 (2019) 249-260.

${ }_{5}^{5}$ Barlaam and Ioasaph. Ed. J. Henderson. Loeb Classical Library (LCL 34). Cambridge - Massachusetts - London $1967\left(1914^{1}\right)$.

${ }^{6}$ Historia animae utilis de Barlaam et Ioasaph. In: Die Schriften des Johannes von Damaskos. VI/1-2. Ed. R. Volk. Berlin - New York 2006.

7 Egedi-Kovács: i. m. (4. jegyz.) 85-95, passim. 
kérdése merőben új megvilágításba kerülnek. Véleményem szerint a francia fordító csak úgy férhetett hozzá a feltételezett munkapéldányhoz, és csak úgy másolhatta be a szöveg alapján készült fordítását az ivironi kódexbe, ha a két kézirat - az ivironi kódex és a másolói példány - a francia fordítás készítésekor még egy helyen volt (az Athós-hegyi Iviron kolostorban őrzött kódex ugyanis, ahogy azt a bevezetőben jeleztük, eredetileg Konstantinápolyban készülhetett). Nehezen hihető az is, hogy a görög nyelvü ivironi kódex és a margón szereplő ófrancia fordítás készítése között több mint száz év telt volna el. ${ }^{8}$ Valószínűbb azt feltételezni, hogy a két írnok - a görög másoló és a francia fordító - közel egy időben és esetlegesen egy megbízási folyamat részeként tevékenykedett, az ófrancia fordítás pedig a korábban feltételezettnél sokkal régebbi.

Tanulmányomban továbbra is a kódex különféle rétegeinek (ógörög szöveg, miniatúrák, ófrancia fordítás) összefüggéseit, azok készítésének körülményeit igyekszem árnyalni, mindezt azonban ismét újabb megközelítésből, eddig nem vizsgált szempontok bevonásával. Korábbi írásaimban már jeleztem, hogy az ófrancia változatban - a görögtől eltérően - piros tintával kiemelt mondatok is szerepelnek, amelyek feltételezhetően képcímek lehetnek. ${ }^{9}$ A kutatás e szakaszában a képcímeknek csupán töredékét sikerült helyreállítanom, mert a barna tintával írott ófrancia szövegben itt-ott felbukkanó rubrikák kizárólag azon a néhány színes fényképen látszottak, amelyeket a miniatúrákról a The Treasures of Mount Athos című kiállításvezető számára készítettek. ${ }^{10} \mathrm{~A}$ kódex egészéről ezidáig kizárólag fekete-fehér képsorozat készült, amely alapján nehéz különbséget tenni a barna és piros tintával írt betűk között. Támpontot csupán az jelentett, hogy a címsorok legtöbbször a képek közelében szerepelnek, és sok esetben a betűk vastagabbak. Az ófrancia címsor-töredékek helyreállítása ráadásul a főszöveg rekonstruálásánál is nehezebbnek bizonyult, hiszen ezekhez semmilyen szöveges támpont nem áll rendelkezésre, a mondatok ugyanis nem szerepelnek az ivironi kódex görög föszövegében. Az ófrancia fordítás teljes átírása után azonban egyértelművé vált, hogy a szöveg minden olyan pontján szerepel címsor, ahol a görög eredetiben illusztráció szakítja meg a regény szövegét. Bár a pirossal kiemelt címsorok a legtöbb esetben kapcsolódnak a miniatúrán ábrázolt jelenethez, nem tekinthetők egyszerű képleírásnak, sőt, sok esetben inkább tűnnek a regény adott fejezetéhez igazodó tartalmi összefoglalásnak/fejezetcímnek, mint képcímnek. Zavarba ejtő ugyanakkor az a jelenség, hogy néhány esetben ott is találunk az ófrancia szövegben címet, ahol a görög szöveg ugyanazon pontján nincs miniatúra a kéziratban. A képekhez kapcsolódó magyarázó szöveg beillesztése nem egyedi jelenség a Barlám-regény kézirati hagyományában. A regényes szentéletnek

${ }^{8}$ Paul Meyer 1866-ban publikált tanulmányában a francia fordítást az általa vizsgált néhány töredék alapján még a XIII. század legelejére datálta. P. Meyer: Fragments d'une ancienne traduction française de Barlaam et Joasaph faite sur le texte grec au commencement du treizième siècle. In: Bibliothèque de l'École des chartes 27/ II. Paris 1866. 313-334.

${ }^{9}$ Egedi-Kovács: i. m. (4. jegyz.) La traduction française 85-86; Egedi-Kovács: i. m. (4. jegyz.) Un trésor inexploré 116-120; Egedi-Kovács: i. m. (4. jegyz.) A Barlám és Jozafát regény kétnyelvű változata 65-72.

${ }^{10}$ S. M. Pelekanides - P. C. Christou - C. Tsioumis - S. N. Kadas (eds.): The Treasures of Mount Athos, Illuminated Manuscripts. Athens 1975².60-91. 
hat illusztrált változata maradt fenn, ${ }^{11}$ ezek közül négy ${ }^{12}$ tartalmaz görög nyelvű képcímeket. További hat kéziratban képek nem, csupán magyarázó feliratok szerepelnek (egyes esetekben az üresen maradt helyek alapján feltételezhetjük, hogy a kéziratba eredetileg terveztek illusztrációt is). ${ }^{13}$ A Barlám-regény esetében úgy tűnik, nem csupán a mű főszövegének, de a képmagyarázó feliratoknak is önálló szöveghagyománya lehetett, amelyet Robert Volk három ciklusra különít el. ${ }^{14}$

Az ófrancia címsorok ugyan filológiai szempontból szorosan nem köthetők egyik ciklus szöveghagyományához sem, mégis sok tekintetben hasonló vonásokat mutatnak. Az ófrancia címek is - akár a görög címsorok - a legtöbbször kerek, egész mondatokból állnak, a képek mellett nem csupán egy-egy szó vagy az ábrázolt szereplő neve olvasható. A görög és az ófrancia címsorok nem egyszerűen képleírások, hanem sok esetben fejezetcímnek, az adott epizód tartalmi összefoglalójának tűnnek. Az ivironi kódexben a címsorok helyét az ófrancia szövegben esetenként hullámos vonal jelöli (a görög szövegben minden esetben hullámos vonal szerepel a képet megelőző mondat végén). A francia fordító minden bizonnyal a képcímeket - miként minden bizonnyal a fordítást magát is - előbb másutt, más íráshordozón készíthette el, a kéziratba pedig a végleges változatot másolta be, javításokat ugyanis ritkán találunk a szövegben. Feltételezhető az is, hogy a piros címeket további, önálló munkafolyamat során másolta be a francia írnok. Erről árulkodnak a kódex azon oldalai, ahol, bár az illusztrációt megelőző adott szövegrésznél piros tintás cím nem szerepel, a helye üresen marad. A görög szöveg esetében hasonló jelenséget figyelhetünk meg: egy helyen (f. 39v) a mondatkezdő, arany tintával megfestett majuszkulát felejti el bemásolni a görög írnok.

Az ivironi kódex miniatúráinak tanulmányozását további két illusztrált Barlám-kézirat képei segíthetik. Egyfelől a BnF Gr. 1128 kéziratban szereplő, a regény hosszú változatához készült képsorozat, másfelől a King’s College 45 kódex margójára utólag bemásolt rajzok, amelyek az ivironi kézirat illusztrációival szoros egyezést mutatnak. ${ }^{15}$ Ez utóbbi kézirat segítségével, amint azt a későbbiekben láthatjuk, akár olyan miniatúrák tartalmával kapcsolatban is értékes ismeretekhez juthatunk, amelyek az ivironi kódex mára elveszett foliumain szerepelhettek. Mindez az ófrancia címsorok tanulmányozása kapcsán nyer különös jelentőséget (lásd alább).

Az alábbiakban az ivironi kéziratban szereplő összes ófrancia címsor átírását közlöm, a hozzájuk tartozó miniatúrákon ábrázolt jelenetek pontos leírásával együtt. A képcímeket az alábbiak szerint csoportosítom:

11 Athos, Iviron Monastery, cod. 463; Jerusalem, Greek Patriarchal Library, Stavrou 42; Ioannina, Zosimaia Library, cod. 1; Paris, Bibliothèque nationale de France, Par. Gr. 1128; Sinai, Monastery of Saint Catherine, Sin. Gr. 392; Cambridge, King's College Library, cod. 45. Lásd Toumpouri: i. m. (1. jegyz.) Barlaam and Ioasaph 150.

12 Sin. Gr. 392; Ioannina, Zosimaia Library, cod. 1; Jerusalem, Stavrou 42; BnF gr. 1128.

13 Toumpouri: i. m. (1. jegyz.) Barlaam and Ioasaph 167-168.

14 Volk: i. m. (6. jegyz.) VI/1. 525-581.

15 Az ivironi kézirat vagy annak egy későbbi másolata szolgálhatott modellként a cambridge-i kódex margójára utólag megrajzolt képekhez. Lásd Toumpouri: i. m. (1. jegyz.) Barlaam and Ioasaph 153. 
1. Az első csoporthoz azokat a címeket soroltam, amelyek a hozzájuk tartozó miniatúra tartalmát pontosan leírják.

2. A második csoportban azok a címek szerepelnek, amelyek kevésbé köthetők a képen ábrázolt jelenethez, inkább tartalmi összefoglalónak, fejezetcímnek tűnnek.

3. A harmadik csoportban azok a példák szerepelnek, ahol - noha a kéziratban találunk miniatúrát - címsor mégsem szerepel az ófrancia szövegben.

4. A negyedik csoport, amely valamennyi közül a legérdekesebbnek tünik, ennek épp az ellentéte: azon címsorokat foglalja magába, amelyekhez furcsamód nem tartozik illusztráció.

5. Végül az ötödik csoportba sorolva szerepelnek azon példák, amelyeknél nem lehet egyértelműen véleményt alkotni. Egyes esetekben az ófrancia cím túlzottan töredékes ahhoz, hogy a mondat jelentése megállapítható legyen, egy folium esetében pedig nem csupán a címsor töredékes, de a kézirat megrongálódása miatt a miniatúrán szereplő jelenet sem látható.

A példák a folium számozásnak megfelelő sorrendben, egymás után szerepelnek: elsőként az ófrancia címet, majd a miniatúrán ábrázolt jelenet leírását közlöm, mindezt pedig néhány esetben szöveges magyarázattal egészítem ki.

\section{A miniatúrán ábrázolt jelenetet követő címsorok:}

f. $4^{\text {r: }}$ Ci est come[nt] li seins Thomas [preecha] sa evangile [e] converti [le po]ple del Ynde

Miniatúra: A képen Tamás apostol látható, amint Indiában az evangéliumot hirdeti.

A $7^{\mathrm{r}}$ foliumon szereplő miniatúrán ugyan két önálló jelenet látható, a francia cím csak az elsőt írja le:

f. $7^{\text {r: }}$ Si cum il fu amenés devant li rois

Miniatúra: A király és az ájtatos satrapa. A satrapa visszatérése a sivatagba.

A $8^{v}$ folium miniatúrájához tartozó cím a lap alján, közvetlenül a kép alatt szerepel, ám jól látható, hogy eredetileg a cím helye, miként más esetekben, úgy itt is a megfelelő szöveghelynél az oldalsó margón lett volna: ugyanezen az oldalon a francia szövegben a címsor eredetileg tervezett helyét hullámos vonal jelöli, utána többsornyi hely üresen marad.

f. $8^{\mathrm{v}}$ : Si cum li filz del roi Joasaf fu nés e de la profecie de l'austronomien Miniatúra: A kép bal felén Jozafát születése, jobb felén a király és az asztrológusok láthatók. 
A „születés” ábrázolásának minden bizonnyal a bizánci kéziratokban kialakult hagyománya lehetett. Az ivironi kódex miniatúráján ábrázolt jelenet (Jozafát születése) szembetűnő egyezést mutat (a képen szereplő személyek és tárgyak hasonló elrendezése, színek egyezése stb.) több más kézirat illusztrációjával (Cf. BnF Gr. 1128, f. 10v; Jerusalem, Timiou Staurou, 042, f. 16 ; Vat. Gr. 333, f. 51 ${ }^{v}$ [a vatikáni kódex Jézus születését ábrázolja, ám ugyanazt a képi megjelenítést találjuk benne, mint a Barlám-kéziratokban]).

A $11^{v}$ foliumon található miniatúrán két önálló jelenet látható, a francia cím a második jelenethez köthető:

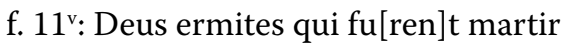

Miniatúra: A kép első jelenetében a király két szerzetessel találkozik. A kép második jelenetében a szerzeteseket megégetik.

A $14^{\mathrm{r}}$ foliumon található címsor végét nem lehet helyreállítani, de a mondatkezdet alapján a szöveg a kép tartalmát követhette:

f. $14^{\mathrm{r}}$ : Coment li filz l[i rois] conplein[t sun] pere de ce qu'il [...]

Miniatúra: A kép első felén Jozafát és a király látható: Jozafát apját kérleli, hogy elhagyhassa a palotát. A kép második felén Jozafát szolga kíséretében lovon távozik a palotából.

Az alábbi esetben a miniatúra ugyan a $15^{\mathrm{r}}$ foliumon szerepel, az ófrancia címsor a görög eredetiben kijelölt szöveghely szerint - az azt megelőző oldalon, a 14v foliumon olvasható:

f. $14^{\mathrm{v}}$ : Cum il encontra le mesiau e l'avogle

Miniatúra (f. 15r): Jozafát találkozása a vakkal és a leprással.

f. 15: Cum il [en]contra le [vell]ar

Miniatúra: Jozafát találkozása az öregemberrel.

A $18^{\mathrm{r}}$ folium miniatúrájához köthető képcím szintén a görög eredetihez igazodó szöveghelyénél, egy oldallal előbb, a $17^{\mathrm{v}}$ foliumon szerepel:

f. 17v: Coment Barlaham parla au jovenceau qui li feist son mesaje

Miniatúra (f. 18 ): A képen Barlám és az ifjú szolgáló látható, akit Barlám arra kér, hogy engedje őt ura elé. A kép másik részén a szolgáló Jozafáttal beszél.

f. 19v: Coment li jovenciaus le cunta au fil del roi e il co[man]da q'il venit avant Miniatúra: A kép azt a jelenetet ábrázolja, ahol Jozafát a szolgát utasítja: engedje be Barlámot. A kép második felén Barlám és Jozafát találkozása látható. 
f. 22r: C[oment envoia] businer [a sun huis] de sun fre[re]

Miniatúra: A miniatúra a halál trombitájának történetéhez kapcsolódik. A kép első felén a halálos ítéletet hirdető trombitás alakja látható, akit a történet szerint a király - tanító célzattal - saját fivére háza elé küld. A kép másik felén a halálra rémült férfi látható, aki családjával együtt a király elé járul.

f. $25^{\text {r: }}$ Coment de[u] perdi les [homes e] en arche [...]..lur ses enf[ans ..]

Miniatúra: A kép a bibliai özönvíz jelenetét ábrázolja: két oldalt vízbe fúlt emberek teste, középen Noé és bárkája látható.

A $39^{\mathrm{r}}$ folium miniatúrájához tartozó címsor a $41^{\mathrm{v}}$ foliumon szerepel. A kézirat lapjai egy korábbi szétszedés során cserélődhettek fel, a jelenlegi 41-es számozású folium eredetileg a 38-as folium után következett. Az ófrancia címsor a szövegrésznek megfelelő helyen szerepel:

f. 41 ${ }^{\mathrm{v}}{ }^{16}$ Ici li reconte un autre exemple d'un home qui avoit trois amis

A miniatúrán ábrázolt jelenet (f. 39²): A képen négy különböző jelenet látható, amely a regény egyik példabeszédének, a férfi és három barátjának történetét mutatja be.

Jóllehet az $53^{v}$ folium miniatúráján áldozás nem, csupán keresztelés látható, a francia címben a BnF Gr. 1128 kézirat címfeliratához hasonlóan áldozásra utaló szó is szerepel („le comunia” = 'beavatja a szentáldozatba'):

f. 53ㄴ: Coment [le bap]tiza e [l]e [com]unia e [...]

Miniatúra: A kép első felén vélhetően Jozafát megtérése látható (Barlám és Jozafát ül egymással szemben), a kép második fele Jozafát megkeresztelését ábrázolja.

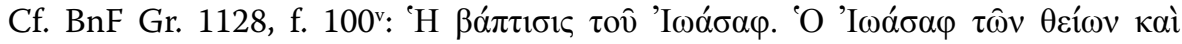

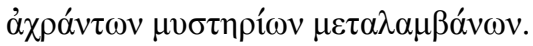

Miniatúra (BnF Gr. 1128, f. 100v): A kép első felén Jozafát keresztelése látható, a második felén Jozafát az áldozás szentségében részesül.

f. 56v: Zardans [ala devant l]e fil del roi [e de Ba]rlaam parloit a lui Miniatúra: A képen Zardan, Jozafát és Barlám szerepel.

f. 57' ${ }^{\text {r }}$ Li filz del roi [dit a] Zardam qu'il [cachast] dedens la cor[tine] e escoutast [li] predicaci[un de] Barlaam

Miniatúra: A kép első felén Zardan függöny mögé bújik, hogy onnan hallgassa Barlám beszédét. A kép második felén Zardan és Jozafát látható. szerepel.

${ }^{16}$ A foliumok felcserélődése miatt hibás a számozás. A képcím a szöveghelynek megfelelő helyen 
f. 59r: Joasaf di[t bien]venu e B[arlaam] li dona con[sel. Co]ment Bar[laam ..] e refusa lo[...]

Miniatúra: A kép két jelenetet ábrázol: mindkettőn Barlám és Jozafát egymással szemben ülnek.

f. 60v: [Co]ment Bar[laam env]oia a Joa[saf sa vest]ure qu'il [o]t requise e co[ment il ot] congié e s'en [ala a] l'ermitage

Miniatúra: A képen három különálló jelenet található: Barlám zálogul adja a kabátját, búcsút int Jozafátnak, majd távozik.

f. 61: Quel vie menoit [apres q]ue Bar[laam] s'en fu [alés]

Miniatúra: A kép mindkét jelenetén az imádkozó Jozafát látható.

f. $62^{\text {v: }}$ Coment [Zar]dam fu ma[lade] por la pe[ur qu'il] avoit del roi

Miniatúra: A kép első részén a betegen fekvő Zardan szerepel, amint orvos gyógyítja. A második részén szintén ő látható, épp Jozafát elé járul.

f. 63: Comen[t] cont[a Zar]dam au [roi de] sun fil [e avo]it crem[or]

Miniatúra: A miniatúrán két jelenet szerepel, mindkettőn Zardan és a király látható.

f. 64: Coment 1 [i roi coman] da Arach[el qu'il di] se le vra[i e] de faire [querre] Barlaam le quin $[\ldots]$

Miniatúra: A kép három epizódot jelenít meg: az elsőn a király és Arachés szerepel, amint tanácskoznak, majd a király kíséretével együtt kilovagol, hogy (a történet szerint) Jozafát mesterét, Barlámot megkeressék, végül a kép utolsó részén ismét a király és Arachés látható.

f. $66^{\mathrm{v}}$ : [Li moine] furent amen[és ...] aitein au roi [Avenir q]ui les fist [m]artirier Miniatúra: A kép első felén szerzetesek állnak a király előtt, a második felén a király jelenlétében egy szerzetest ostoroznak.

f. $68^{\mathrm{r}}:[\ldots]$ ques mart [ir] furent

Miniatúra: A képen ugyancsak Abenér király jelenlétében szerzeteseket kínoznak meg.

f. 69: Arache[1 comanda] Nacor [qu'il fu] ist ensembl[able que] Barlaa[m] Miniatúra: A miniatúra három jelenetet ábrázol: az elsőn a király és Arachés látható, a másodikon Arachés felkeresi Nakhórt a barlangjában, a harmadikon Arachés kíséretével ismét elmegy Nakhórhoz, hogy a király elé vezesse őt. 
f. 69v: Co]ment un ame[na Nac] or devant le roi [e dist] un par traisun que [cil estoit B] arlaam e coment [Joasaf] fu comfortés [par une r] evelacium

Miniatúra: A miniatúrán három jelenet szerepel: Nakhórt a király elé viszik, Jozafát egy látomásban megtudja az igazságot, majd ismét Jozafát látható trónszékén ülve.

f. $70^{v}$ : Co[ment li roi]s laidenga cru[element sun] fil e coment Joa[saf reg]ehi Jesu Crist [am]oreusement

Miniatúra: A képen ábrázolt két jelenetben előbb a király látható, amint fiát, Jozafátot lakosztályában felkeresi, majd a kép második felén egymással beszélnek.

f. 73v: Co[ment li] rois s'en parti [irous] ement e Joasaf [dist a lui] sun adeu Miniatúra: A kép sajátos formában - a kronológiai sorrendtől eltérő módon ábrázol három különálló jelenetet: a miniatúra közepén látható Abenér, amint a fiával beszél, az a jelenet azonban, amikor a király kíséretével együtt haragosan távozik, meglepő módon a kép bal oldalára kerül, míg a kép jobb szélén Jozafát ismét egyedül látható.

f. 74v: Coment Arachel consella le roi qu'il le atra[ist]

Miniatúra: A képen a király látható, amint Arachés tanácsát kéri.

f. $74^{\mathrm{v}}$ : Coment li rois atra[ist sun fi]l par blandise [e] coment Joasaf se [tint ferm] ement el savoir [d]e Deu

Miniatúra: A kép első részén a király és Jozafát karjaikat egymás felé nyújtva, ölelkezve ülnek egymással szemben. A miniatúra második részén állnak, Jozafát elfordítja fejét apjától, mögöttük szolga látható.

f. $83^{\mathrm{v}}$ : Coment li ro[is e si] retorien fu[rent ..]..d abaubi [e com] ent Joasaf [dem]anda Nacor [...]

Miniatúra: A kép bal felén a király és Jozafát látható, körülöttük a megdöbbent rétorok, valamint a magát Barlámnak kiadó Nákhór. A miniatúra jobb felén Jozafát Nákhórral és kíséretével együtt lovon távozik.

f. 84v : Coment li [fils del] roi converti [Nacor] e le pria [po]r merci [de deu e do]ctrina qu'il feroit

Miniatúra: A képen két jelenet látható: Jozafát Nákhórral és kíséretével ellovagol, ezután Jozafát Nákhórhoz beszédet intéz. 
f. $87^{\text {r: }}$ Coment [Joasaf] dona pais a [Nacor] e l'envoia en [ermi]taje e com[ent Nacor] fu baptisiés [e vesqui] en pena[nce]

Miniatúra: A miniatúra négy jelenetet ábrázol: Jozafát megöleli Nákhórt, aki ezután távozik. A kép következő részén Nákhór látható a pusztában, amint egy szerzetes előtt meghajol. A kép zárójelenetében a szerzetes megkereszteli Nákhórt.

f. $88^{v}$ : Coment li pretre des ydres alerent [a l'encontre d'u]n enchanteur qui avoit a num Teldas en lor aide e coment [T] eldas enprist guerr[e contre] la foi des xpiens Miniatúra: A miniatúra három jelenetben ábrázolja, amint a bálványimádó pap kíséretével együtt felkeresi Theudast, a varázslót.

f. 89v: Co]ment li ro[is] ala a l'encon[tre de T]elda e le fist [venir ve]rs lui e le con[sel qu'il] dona au roi

Miniatúra: A király karját nyújtva üdvözli Theudast, majd egymással szemben ülve tanácskoznak.

f. $90^{v}$ : Coment Teldas envoia les roiaus letres e fist au roi e au pople faire feste as deables

Miniatúra: A kép bal felén Theudas a király mellett ül, és levelet nyújt át egy szolgának, a kép jobb felén a király, Theudas és további szereplők láthatók, amint áldozatot mutatnak be egy pogány szentélyben.

f. 95 $5^{\mathrm{r}}$ : Com[ent] li deables [le vout] sosplanter [par] ceste femm[e]

Miniatúra: Királylányt küldenek Jozafáthoz, hogy megpróbálja őt elcsábítani. A kép első felén két hajadon vezeti a lányt a palotához, a kép második felén a királylány Jozafát előtt áll.

f. 100: Coment no[stre] sires li mo[stra] par visiu[n la] joie de pa[radis]

Miniatúra: A kép bal szélén Jozafát előbb állva, majd leborulva imádkozik. A kép jobb szélén Jozafát látható, amint álmában megpillantja a Paradicsomot, mellette két angyal áll.

f. $101^{\mathrm{r}}$ : Co[ment] il vit en celle [vi]siun les pein[es] d'infe[r]

Miniatúra: Jozafát a látomásban megismeri a Poklot is. A miniatúra négy részre van osztva: a kép első felén Jozafát látható továbbra is két angyal kíséretében, a másik három jelenetben az elkárhozott lelkek pokolbéli útjának állomásait ábrázolták: az első képkockán sötét alapon emberi arcok látszanak, a második képkockán vörös színủ alapon fejek láthatók (a kép a tisztítótüzet ábrázolhatja), a harmadik, szintén sötét színnel megfestett képkockán arcok helyett már csupán koponyák látszanak. 
A képcím az ófrancia fordítás megfelelő szöveghelyénél, a miniatúra előtti lapon, a $101^{v}$ foliumon szerepel:

f. 101": Coment li rois vint vooir sun fil qui gisoit malades e coment li filz se conpleinst al pere de ce qui li avoit fait e li pria qu'il ne le desturbast plus de bien faire

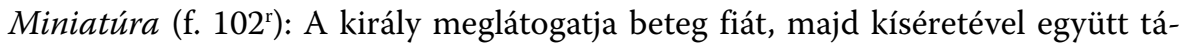
vozik.

A $102^{v}$ folium miniatúráján eredetileg démonok is szerepelhettek, miként azt a BnF Gr. 1128-as kézirat $158^{\mathrm{r}}$ foliumának második illusztrációján láthatjuk: a párizsi kódexképen a barlangban ülő Theudas előtt sötét színű, szárnyas démonok jelennek meg. Az ivironi kódex miniatúráján csak Theudas alakja látható jól kivehetően, épp barlangjában ül. A képen ugyanakkor néhány elmosódott sötét folt látszik Theudas alakja mellett, amelyek talán szárnyas alakokat formálnak:

f. 102v: Coment li ma[ligne] esprit re[torne]rent qu'il estoit $[\ldots] s$ confit par la [ver]tu de Crist

Miniatúra: A gonosz lelkek visszatérnek Theudashoz.

f. 103" : [Comen]t li rois me[na Tel]dam por dispu[ter con]tre sun fil e [coment J]oasaf lor [mostr] a vigorose[ment] la droite foi

Miniatúra: A kép első felén a király Theudasszal beszél, a második felén a király és Theudas felkeresik Jozafátot.

A címsor a $107^{\mathrm{r}}$ foliumon szerepel a megfelelő szöveghelynél, a fél oldalt kitöltő, nagy méretü kép azonban a következő lapon (f. 107) található:

f. 107: Coment Teldas s'ap[er]çut de la vertu de la predicaciun e regehi devant le roi la verté e se [con]ver[ti]

Miniatúra (f. 107v): A képen a király, Jozafát és Theudas látható, több más szereplővel együtt. A jelenet Theudas megtérését ábrázolja.

f. 108 : [Com]ent li rois [demanda con]sel qu'il fero[it ...] sun fil e co[ment] le fist r[ois] de la moitié de [sun pais]

Miniatúra: A miniatúra azt a jelenetet ábrázolja, amelyben Abenér fele királyságát Jozafátra hagyja. A képen három önálló jelenet látható: a király előbb néhány emberével tanácskozik, a kép középső részén Jozafát ül a trónon, mellette Abenér foglal helyet, a kép utolsó részén ismét Jozafát látható, amint kísérőivel ellovagol. 
f. $113^{\mathrm{v}}$ : [Coment] il estoit lar[ge a]umoniers [as povres e mis] ericors as [ho]nteus e com[ent] sa bone re[no]mee s'espandoient

Miniatúra: A kép azt a jelenetet ábrázolja, amelyben Jozafát bőkezűen alamizsnát oszt a szegényeknek. A kép bal felén Jozafát látható, amint trónján ülve három férfit fogad, az egyiküknek pénzt nyújt át. A kép jobb felén a három férfi távozik a palotából, szembe velük újabb három ember érkezik.

f. 114v : Co]ment li rois A[v]ennir se porsa[... e] envoia letre [a] sun fil Miniatúra: A képen Abenér király látható, amint alattvalói jelenlétében levelet nyújt át egy szolgának, aki ezután a levéllel együtt ellovagol.

Feltételezhető, hogy a $116^{\mathrm{r}}$ folium illusztrációja azt a jelenetet ábrázolja, amelyben Jozafát megkapja apja hozzá írt levelét. A levél azonban nem látszik egyértelműen a miniatúrán. Jozafát a kezében talán tart valamit, a ruháján (a tenyere mögött) ugyanis fehér folt látható:

f. 116 : Coment rois Joasaf $\mathrm{m}$ [ercia] deu en ler[mes] de sun pere q[u'il avoit] porpensés d[e lui]

Miniatúra: A kép bal oldalán Jozafát ül trónján, előtte két alak áll, az egyikük fejet hajt Jozafát előtt. A miniatúra jobb oldalán Jozafát a földön térdelve ad hálát Istennek.

A BnF Gr. 1128-as kódex $173^{r}$ foliumán szereplő illusztráción Jozafát egyértelműen levelet tart a kezében, amely olyan nagy méretű, hogy néhány görög szó is olvasható rajta.

f. $40:{ }^{r}:{ }^{17}$ [Coment li filz] li rois Joa[saf ala] a sun pere li em[braça vi] vement e co[ment fu esjo]is ses pere[s qui le re]çut a gran[t joie]

Miniatúra: A kép bal felén Jozafát látható, amint kíséretével megérkezik apja palotájához. A kép jobb felén Abenér király nagy örömmel öleli át fiát.

A $40^{\mathrm{r}}$ foliumon szereplő második címsor a $40^{\mathrm{v}}$ folium miniatúrájához tartozik. A francia cím a megfelelő szövegrésznél szerepel. Ugyanakkor kézenfekvő lehetett, hogy a francia írnok a címet a miniatúra elötti oldalra másolta be, mivel a $40^{\mathrm{r}}$ folium alsó margóján a szokottnál is nagyobb felület maradt üresen a görög szöveg alatt:

f. 40: Coment li filz ensegn[a a sun] pere les sacremens de nostre deu e coment li rois Avennir se conver[ti premier]ement e aora la crois e depeça les ydres e del pople qui fu convertis

17 A 40-es folium számozása hibás, a lap eredetileg a 116-os folium után következett. 
Miniatúra (f. 40v): A képen három jelenet látható: előbb Jozafát beszél apjához, aki ezek után a kereszt előtt meghajol, végül ismét a király látható a képen, amint alattvalóit is megtéríti.

f. 118 : Co[ment li ro]is Avennir [fu bap]tisiés e Joa[saf fu] parrein[s de sun] pere e e[spiritu]ex pa[roles ...]

Miniatúra: A képen előbb Abenér király látszik, egy pap beszél hozzá, majd a pap megkereszteli őt. A keresztelő közben Jozafát, mint keresztszülő, apja mellett áll, kezében törlőruhát tart.

f. $118^{v}$ : Co]ment li rois Avennir livra tot le regne a sun fil e deguerpi tot e ve[squi e]n parfaite penance e coment il trespasa

Miniatúra (f. 119r): A kép három részből áll: az első felén az a jelenet látható, amelyben Abenér a teljes királyságot átadja fiának: Abenér egyszerủ széken ül, kezét fia felé nyúitja, a trónszéken Jozafát foglal helyet. A miniatúra középső felén Abenér elhagyja a palotát, a kép jobb szélén pedig már a halála elött, ágyban fekve látható, Jozafát öleli át, mellettük szolga áll.

f. $120^{\text {r: }}$ Com[ent ro] is Joasaf fist $1[i$ ser]vise de sun pe[re e] coment pard[ura avoc] lui VII io[rs ..] su[...]

Miniatúra: A miniatúrán Jozafát látható másodmagával, amint apja ravatala mellett áll. A kép jobb felén úgy tünik, Jozafát szertartást végez egy szentélyben.

A $120^{v}$ folium miniatúráján vélhetően az a jelenet szerepel, amelyben Jozafát szétosztja vagyonát alattvalói között:

f. $120^{v}$ : Co[ment] li rois Joa[saf ...]adida ses tres[ors] par les aumones [qu'il fi] st e se desconbra [de tot li] avoir del munde

Miniatúra: A képen Jozafát ül a palotában, mögötte őr áll. Négyen járulnak elé, akiknek Jozafát átnyújt valamit.

Az ivironi kódex miniatúráján nem látszik pontosan, hogy Jozafát mit tart a kezében. A King's College 45 jelzetű kéziratban az adott szöveghelynél, a $174^{v}$ foliumon az ivironi képhez hasonló elrendezésủ rajz található. Ezen jól látszik, hogy Jozafát ruhákat ad az előtte állóknak.

f. 121' : Coment l[i] pople asambl[a e] mostra qu'il [volo]it le munde [laisi]er e qu'il feis[t $\ldots .$.

Miniatúra: A miniatúra azt a jelenetet ábrázolja, amelyben Jozafát tudatja alattvalóival távozását. A képen Jozafát ül, előtte többek állnak. 
A $122^{v}$ folium felső margóján olvasható címsor első fele szinte teljesen megsemmisült. A mondat záró szakasza alapján azonban úgy tűnik, a cím illeszkedhetett a miniatúrán ábrázolt jelenethez:

f. $122^{\mathrm{v}}:$ [ e coment por lui e por les autres e puis lor dona congié

Miniatúra: A miniatúra első felén Jozafát látható, amint a tőle balra álló Barachiasra mutat, jobbra tőle alattvalói állnak, középen Jozafát Barachias fejére helyezi a koronát, majd távozik, végül újra Jozafát látható, amint népétől búcsút vesz.

f. $123^{\mathrm{v}}$ : Coment Joasaf deguerpi sun [pople] e totes riens [e s'en fu al]és por la [verité de] Jesu Crist

Miniatúra: A miniatúra bal szélén Jozafát látható, amint elhagyja a palotát, az újonnan megválasztott király, Barachias pedig két másik emberrel együtt búcsút int neki. A kép közepén Jozafát leveti, és egy szerzetesnek adja királyi öltözékét (a korábbi miniatúrák mindegyikén ábrázolt, kék színű, barnával szegélyezett ruháját). A kép zárójelenetében Jozafát a pusztában vadállatokkal találja szemben magát.

f. 128v: Coment Bar[laam] doctrina Joasaf [sent]ant sun trespas[em]ent e li dist qu'il le me[si]st en terre

Miniatúra: A képen Barlám és Jozafát látható a pusztában: egymással szemben ülnek, mögöttük hegyek és két kisebb épület, vélhetően szerzetesi lakhelyek láthatók.

f. 129v: [Coment Jo] asaf trova [une rive] estancha sa soif [e graces ren]doit a deu qu'il li [..]st Barlaam

Miniatúra: A képen, a címnek megfelelően, három jelenet látható: Jozafát a pusztában folyóra talál, iszik a vizéből, majd fejét az ég felé fordítva hálát ad Istennek.

f. 134r: Coment Jo[asaf] vesqui fervans en l'amor de deu e coment trespasa de cest siecle

Miniatúra: A kép Jozafátot ábrázolja szakállal, kissé megöregedve, amint arcát az ég felé emeli, kezeit imára kulcsolja. A kép középső felén Jozafát holttestét egy szerzetes sírba helyezi. A kép jobb szélén újra a szerzetes látszik, amint útnak indul, és egy angyal mutatja az utat előtte lebegve.

f. 135" : Coment cil pri[st] le comandement [e] ala au rois [por con]ter de Joasaf Miniatúra: A képen az említett szerzetes az újonnan megválasztott király, Barachias színe elé járul, mellette további három alak látszik. 
2. Tartalmi összefoglalónak, fejezetcímnek tűnő címsorok

A $3^{r}$ foliumon szereplő címsor egyértelműen fejezetcím: a prológust zárja le, és a regény témáját jelöli meg. A miniatúra ezzel szemben a regény helyszínét, az indusok országát ábrázolja:

f. $3^{\text {r: }}$ Li prologes est finés. Ici comence l'estoire de la vie le boneuré Joasaf Miniatúra: A miniatúrán város látszik, amelyet tenger szegélyez. Hajókon emberek érkeznek. A távolban egy másik város képe is kirajzolódik.

A $16^{v}$ foliumon szereplö cím sem közvetlenül a miniatúrán látható jelenetet írja le:

f. 16 : Com il [o]t pensés de la [m] ort

Miniatúra: A kép első felén Jozafát és tanítója látható, a második felén szerzetes (minden bizonnyal Barlám) látható, amint egy barlangban ül, előtte angyal lebeg.

A $16^{v}$ foliumon szereplő címsor annyiban illeszkedik a miniatúra tartalmához, hogy annak első részén vélhetően az a jelenet szerepel, amelyben a történet szerint a betegséggel és elmúlással épp ekkor szembesülő Jozafát tanítóját kezdi faggatni a halál természetéről. A BnF Gr. 1128 kézirat azonos szöveghelyénél, a $21^{v}$ foliumon szereplő illusztráción hasonló kompozíció látható: Jozafát és tanítója egymással szemben áll (az ivironi képen Jozafát széken ül, a ruhák színe azonban megegyezik a két kéziratban), Jozafát kezét nyújtja felé, mindkettőjük mögött épület látható. Egy további Barlám-kéziratban, amelyhez illusztrációk ugyan nem készültek, képcímeket azonban találunk, a kérdéses szöveghelynél a francia címhez hasonló felirat szerepel: Cf. Augsburg, Universitäts-

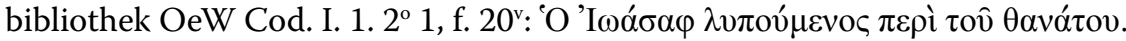

f. 20: Ci comen[ce] la predica[ci]un de Barlah[am a] Joasaf

Miniatúra: A miniatúra a magvetőről szóló példabeszédet ábrázolja. A kép bal felén a magvető látható, jobb felén Barlám, aki Jozafáthoz a példabeszédet intézi.

f. $21^{\mathrm{r}}$ : Ci li conte un exemple d'un roi

Miniatúra: A miniatúra a királyról szóló példabeszédhez köthető. A képen a király látható, amint - a mögötte álló föurak legnagyobb döbbenetére - leszállva kocsijáról, meghajol két szerzetes előtt.

f. 22v: [Ci li cont]e un autre [e]xemple de ce[st]ui roi

Miniatúra: A miniatúra a négy láda történetét ábrázolja. A kép bal felén a ládákat a király elé viszik, a jobb felén a király előtt főurak állnak tanácstalanul, előttük a négy láda, amelyek közül választaniuk kellene. 
A cím a szöveghelyhez igazodva a miniatúra előtt egy oldallal, a $28^{\mathrm{r}}$ foliumon szerepel:

f. 28 ${ }^{\text {r: }}$ Ci parole de la districciun derreine

Miniatúra (f. 28v): A miniatúra az Úr második eljövetelét ábrázolja.

f. $31^{\mathrm{v}}$ : [Ci li] cunte un exem[ple] e puis le doc[tr]ine de bon [e]nsegnement [q]u'il doit faire [e qu']il doit laisi[e]r

Miniatúra: A miniatúra a madarász és a fülemüle történetéhez kapcsolódik. A három részre osztott kép jeleneteket ábrázol a történetből.

f. 44: [Ci li] dit un aut[re e]xemple de ce [qu'un] doit garn[ir en nos]tre siec[le Miniatúra: A miniatúrán a királyról szóló példabeszéd néhány jelenete látható.

f. 47v: Un exe[mple dis]oit soir la [riche]se del siecle e [soi]re la povreté [de la r]eligiun

Miniatúra: A képen a gazdag fiatalokról szóló példabeszéd jelenetei láthatók.

f. 77r: Coment nostre sires parl[oit a caus] qui estoit paiens desconfist le partie des paiens e conferma la foi des xpistiens e lor [...]

Miniatúra: A képen a király által szervezett teológiai vita látható. Középen a király és Jozafát ül, mellettük az „ál-Barlám”, Nákhór áll, körülöttük a vita többi résztvevője, a rétorok láthatók.

f. 94r: Coment li rois par l'es[poir] e Teldas pa[r le] maligne [esprit] se peneren[t en] vain de su[n fil qui fu] le chevali[er de] Jesu Cr[ist]

Miniatúra: A miniatúra azt az epizódot ábrázolja, amelyben a király Theudas tanácsára hajadonokat küld a fiához, hogy elcsábítsák. A képen a király mellett elmosódott alak látható, valószínüleg Theudas, előttük három női alak. A kép második felén négy hajadon veszi körbe Jozafátot.

A $132^{v}$ foliumon olvasható felirat egyértelműen címsor: közvetlenül a kép mellett szerepel, a fordítás épp azon pontján, amely után a görög szövegben is kép következik, a miniatúráról készült színes fényképen ráadásul jól látszik, hogy a betűk piros tintával vannak megformálva. Ennek ellenére a cím nehezen illeszthető a miniatúrán ábrázolt jelenethez:

f. $132^{v}$ : Co[men]t il li dona sa [pais] e sa beneicun [pu]is rendi l'ar[me. E] coment Joasaf [le pl]ora e enterra.

Miniatúra: A miniatúrán három különálló jelenet szerepel: előbb Barlám látható, amint egy házból kilép, majd Barlám és Jozafát látszik, amint megölelik egymást, végül a kép utolsó részén Jozafát Barlám előtt térdepel. 
A címsor szerint a miniatúra azt a jelenetsort ábrázolná, ahol Barlám utoljára megáldja Jozafátot („Coment il li dona sa pais e sa beneicun”), kileheli lelkét („puis rendi l'arme”), majd Jozafát megsiratja és eltemeti mesterét („e coment Joasaf le plora e enterra”), éppen úgy, ahogy a BnF Gr. 1128-as kódex $196^{v}$ foliumán szereplő három jelenetből álló képsorozaton látható, sőt a képek mellett olvasható görög címfeliratok is jelentős egye-

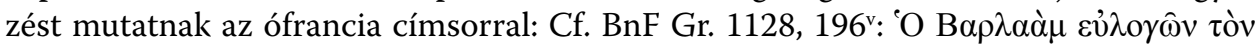

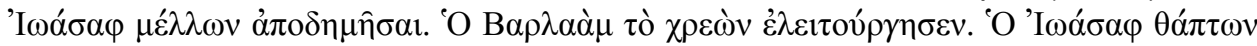

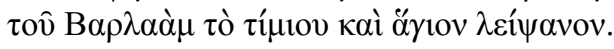

Hasonlóképp a $133^{\mathrm{r}}$ foliumon szereplő címsor sem követi pontosan a miniatúra tartalmát:

f. 133' : Coment vit [une] visiun glori[euse] e l'esperit d[e Bar]laam qui le reprist e com[ent ...]

Miniatúra: A képen Jozafát látható, amint Barlám sírja mellett csüggedten ül, felette angyalok lebegnek. A kép második felén az angyalok vezetésével Jozafát látomásban megpillantja a mennyországot.

A cím egyfelől a sírról nem tesz említést (a jelenet sokkal inkább illeszkedne a $132^{v}$ foliumon szereplő képcímhez), másfelől, a cím szerint nem csupán dicsőséges látomás tárul Jozafát szeme elé („vit une visiun glorieuse”), de mestere, Barlám lelkét is megpillantja („e l'esperit de Barlaam”). Az ivironi kódex miniatúráján Barlám alakja azonban nem látható. Ugyanakkor a párizsi kézirat $198^{\mathrm{r}}$ foliumán található képen a kérdéses jelenet pontosan megfelel az ivironi kódex ófrancia címsorában leírtaknak: Jozafát a sír mellett ülve csodás látomásban angyalokat lát, köztük pedig mesterét, Barlámot. A képhez címsor is kapcsolódik, amely az ábrázolt jelenetet részletesen leírja, és amely egyúttal párhuzam-

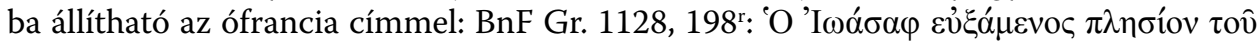

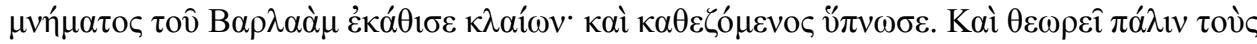

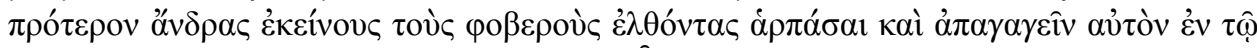

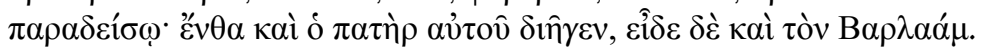

A fent említett két példa alapján azt feltételezzük, hogy az ivironi kódex illusztrátora néhány esetben eltérhetett az általa és a francia fordító által is használt mintapéldánytól (az ezzel kapcsolatos megállapításainkat bővebben lásd alább), ez magyarázhatja a címsor és a miniatúrán ábrázolt jelenet közti eltéréseket.

\section{Miniatúrák képcím nélkül}

A kódex legelső oldalán, az $1^{\mathrm{v}}$ foliumon teljes oldalt kitöltő kép található, amely a mü korábban feltételezett szerzőjét, Damaszkuszi Jánost ábrázolja. A képhez az ófrancia szövegben cím nem tartozik. Az ivironi kódexhez hasonlóan a BnF Gr. 1128 kézirat 
kezdő oldalán is szerepel egész alakos kép, a regény címszereplőjének, Szent Barlámnak a portréja. A párizsi kódex esetében címet is találunk a kép felett: BnF Gr. 1128, 1v

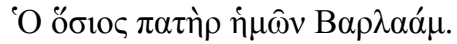

Elképzelhető, hogy Damaszkuszi János portréja az ivironi kódex illusztrátorának saját alkotása volt, a mintaként szolgáló kéziratban a kép nem szerepelt, így cím sem tartozott hozzá, amit a francia fordító beilleszthetett volna.

A $4^{v}$ foliumon Abenér király, valamint a szerzetesek láthatók, képcím azonban a francia szövegben nem szerepel:

Miniatúra (f. 4v): Abenér király és a szerzetesek prédikációja.

Ugyanakkor megfigyelhető, hogy a fordítás adott szöveghelyénél (amely pontosan igazodik a görög szövegben található képhelyhez) több sornyi lapszél marad üresen. Feltételezhető, hogy e helyütt is szerepelt volna piros tintás címsor, amelyet a másoló talán elfelejtett utólag beilleszteni.

Az $5^{v}$ foliumon a görög képhelyhez igazodó szöveghelynél a francia fordításban is hullámos vonal látható, amely más esetekben a képcím helyét jelöli, címsort azonban sem itt, sem közvetlenül a miniatúra mellett nem találunk:

Miniatúra (f. $5^{v}$ ): A képen Abenér király látható, előtte szolga áll, kezében tekercscsel/levéllel, amely a történet szerint a keresztények üldözését elrendelő határozatot tartalmazza. A kép közepén egy keresztény megkínzása látható, a kép jobb szélén barlangokban rejtőzködő szerzetesek szerepelnek.

A miniatúrán ábrázolt jeleneteket további Barlám-kéziratokban is megtaláljuk. A BnF Gr. 1128-as kódex $4^{v}$ foliumán az ivironi kép második és harmadik jelenete szerepel: a kép első felén Abenér király látható, mellette katona áll, aki kínzásnak vet alá egy szerzetest, a kép jobb szélén, barlangokban rejtőzködő szerzetesek látszanak. A Jerusalem Timiou Staurou 042 kódex $8^{v}$ foliumán az ivironi kép első jelenetéhez hasonló illusztrációt találunk: noha a kép erősen megkopott, jól látszik rajta a király, amint trónján ül, kezében tekercset tart, amelyet az előtte álló alak felé nyújt.

Az ivironi kódex $5^{v}$ foliumán szereplő képhez valójában cím is tartozik, azt azonban a másoló hibásan a következő oldal miniatúrája alá másolta be, ahhoz a szövegrészhez, ahol egyébként újabb képcímnek kellene szerepelnie. A $6^{\mathrm{r}}$ folium címsora felett található miniatúra láthatóan a címtől eltérő jelenetet ábrázol:

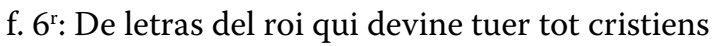

Miniatúra: A kép a történet három epizódját mutatja be: az elsőn Abenér király látható, aki előtt áldozatot mutatnak be a pogány isteneknek. A kép közepén a tör- 
ténet szerint titokban keresztény hitre tért satrapa a palotából távozik. A kép jobb szélén ismét a satrapa látható, amint szerzetesekhez csatlakozik.

Egyértelmű, hogy a kép alatt olvasható címsor az előző oldalon szereplő illusztrációhoz tartozik, hiszen azon látható a keresztények üldözését elrendelő rendelet/levél („letras”). A korábban említett jeruzsálemi kézirat ugyanezen jelenetet ábrázoló képe mellett a francia címsorhoz hasonló felirat is olvasható, a kép mellett, közvetlenül a kézirat margójára másolva: Jerusalem Timiou Staurou 042 kódex 8': 'O $\beta \alpha \sigma \imath \lambda \varepsilon v ̀ c ~ ' A \beta \varepsilon v v n ́ \rho$

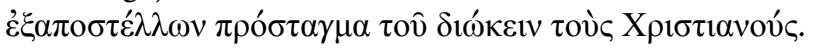

Az ivironi kézirat $6^{\mathrm{r}}$ foliumának miniatúráján ábrázolt három jelenetből csupán az utolsóra találunk más kéziratban példát. A BnF Gr. 1128 kódex $5^{\mathrm{r}}$ foliumán szereplő képen szintén látható a satrapa, amint keresztény szerzetesekhez csatlakozik. A párizsi kódex miniatúráján ábrázolt jelenet kompozíciója sokban hasonlít az ivironi képhez: balra látható a satrapa, kezét kérdőn a mellette álló szerzetes felé nyújtja, aki a többiek irányába mutat. Az ivironi miniatúra első két jelenete (a pogány isteneknek bemutatott áldozat és a satrapa távozása a palotából) ugyanakkor más fennmaradt kéziratban nem szerepel. Nem kizárt tehát, hogy ezek az ivironi kézirat illusztrációinak elkészítése során modellként szolgáló kéziratban sem szerepeltek. Akár az is elképzelhető, hogy ahogyan kép, úgy címsor sem szerepelt a mintapéldányban, ami magyarázatul szolgálhat az ófrancia címsorokkal kapcsolatos tévedésekre, ti. nem a megfelelő kép mellett szerepel a címsor

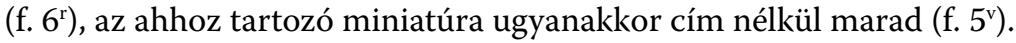

A $26^{v}$ foliumon szereplő miniatúra mellett szintén nem szerepel képcím:

Miniatúra (f. 26v): A bibliai Vörös-tengeren való átkelés jelenete.

A lapon nagyjából a cím helyén (a görög szöveghelyhez képest egy mondattal lejjebb) a francia fordításban több sornyi üres rész látható. Noha a következő folium elveszett, valószínủleg még ezen az oldalon szerepelt volna a piros tintás cím, ám a francia írnok minden bizonnyal elfelejtette azt utólag bemásolni.

\section{Címsorok, amelyekhez nem tartozik miniatúra}

A $2^{\mathrm{r}}$ folium felső és oldalsó margóján található sorok ugyan valószínűleg szintén piros kiemeléssel készültek (a színek a fekete-fehér képeken nem látszanak, ugyanakkor a kérdéses mondat esetében vastagabb és nagyobb a betüméret, mint a következő szövegrésznél), egyértelmű azonban, hogy a mondat nem képcím, illusztráció sem tartozik hozzá, hanem a regény kezdő sorainak fordítása, amely a görög szövegben is nagybetüvel, címsorként szerepel: 
f. $2^{\text {r: }}$ Ici comence une estoire profitable qui avint en la terre del [Ynde] si cum un vait vers Egipte e fu estoree en la seinte cité de Jerusalem Jehan le moine [res]pe[ctable e ho]ms honorab[les del] monast[e]re del seins [Sabas] d'est[oire] de vie [de nostre saints] pere[s Barla]am e [Joasaf]

Cf. f. $2^{\text {r: I } \Sigma}$ TOPIA $\Psi Y X \Omega \Phi E \Lambda H \Sigma$ EK TH $\Sigma$ EN $\Delta$ OTEPA $\Sigma$ T $\Omega N A I \Theta I O \Pi \Omega N$ X $\Omega P A \Sigma$,

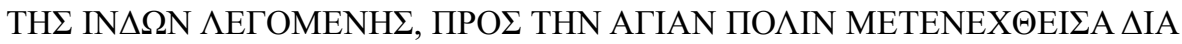
ISANNOY MONAXOY, AN $\triangle P O \Sigma$ TIMIOY KAI ENAPETOY MONH $\Sigma$ TOY AГIOY $\Sigma$ ABA· $\triangle$ IHГOYMENH TON BION T $\Omega N$ O $\Sigma I \Omega N$ ПATEP $\Omega N$ HM $\Omega N$ BAP $\Lambda$ AAM KAI I $\Omega$ A $\Sigma$ A

A $91^{v}$ folium alsó margóján a francia szövegben találunk egy, a görög szövegben nem szereplő, valószínűleg piros tintával írt mondatot, amelyhez azonban nem tartozik miniatúra:

f. $91^{\text {v }}$ : Coment li rois se conpleinst a Telda de sun fil e quel consel Teldas li dona

A kézirat görög szövegének azonos helyén sem hullámos vonal nem szerepel (amely a kép eredetileg tervezett helyét jelölhetné), sem nagyobb helykihagyás nem látható, csupán a mondat végét jelölő vastagabb pont. Egyértelműnek tűnik, hogy a görög másoló-illusztrátor a kézirat ezen részére nem tervezett miniatúrát. Ugyanakkor érdemes megjegyezni, hogy a King's College 45-ös kézirat $139^{r}$ foliumán található kép, amely az említett szöveghelynél szerepel, a francia címnek tökéletesen megfeleltethető jeleneteket ábrázol: a kép első felén a király fogadja Theudast, a jobb oldalán a király és Theudas egymással szemben ülve tanácskoznak. Továbbá érdemes megjegyezni, hogy az augsburgi Barlám-kézirat ugyanezen szöveghelyhez kapcsolódó címsora szintén párhuzamba állítható az ófrancia képcímmel: Cf. Augsburg, Universitätsbibliothek OeW Cod. I.

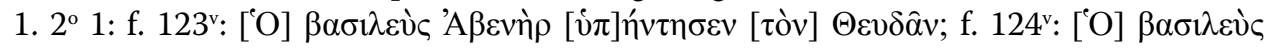

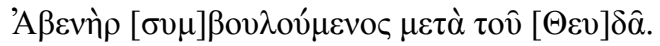

Lehetséges, hogy az ivironi kódexnek mintául szolgáló kéziratban is szerepelt az említett illusztráció (valamint ahhoz képcím is tartozott, amelyet a francia szerző le is fordított), ám a kézirat illusztrátora azt valamilyen okból kihagyta.

A $128^{r}$ folium legalsó részén szintén szerepel címsor, amelyhez kép nem tartozik:

\section{f. $128^{\text {r: }}$ Coment vesquirent ensemble}

A francia írnok láthatóan a szöveg másolásakor nem hagyott helyet a képcím számára, a címsort utólag, az oldal legaljára másolta be. A javítást jelezte: mind a címsor előtt, mind feljebb a szövegben (ott, ahol a címnek valószínűleg szerepelnie kellett volna) kereszt jelölést találunk. A görög szövegben a kérdéses szöveghely után nincs egyértelmű képhelyre utaló jelzés (a mondat végén vastag pont látható, hullámos vonal azonban 
nem szerepel). A King’s College-kézirat ugyanezen szöveghelyénél azonban szintén találunk olyan illusztrációt, amely megfeleltethető az ivironi kódex ófrancia címsorának („Hogyan éltek együtt”). A rajz két jelenetet ábrázol Barlám és Jozafát közös életéről: a kép első felén egymással szemben ülve beszélnek, a másik felén közös asztalnál étkeznek. Ebben az esetben is elképzelhető, hogy a francia fordító a címsort adott minta alapján korábban lefordította, és ugyan kép nem tartozott hozzá a kéziratban, az alsó lapszélre mégis beillesztette azt.

\section{A kézirat megrongálódása miatt nehezen vizsgálható esetek}

Az alábbi esetekben nehéz megállapítani, vajon az ófrancia cím valóban illeszkedett-e a miniatúra tartalmához, mivel ezek szövege erősen töredékes állapotban maradt fenn, a kiolvasható szövegrész alapján pedig nem egyértelmű, mi lehetett eredetileg a mondat tartalma:

f. $110^{\mathrm{r}}:[\ldots]$ regne e coment il fist $[\ldots]$

Miniatúra: A miniatúrán három jelenet látható: a kép bal szélén Jozafát kíséretével ellovagol, középen a pogány bálványszobrok megsemmisítése látszik, a kép jobb szélén ismét Jozafát látható, amint népével együtt egy újonnan épült templomot szemlélnek.

f. $112^{\mathrm{r}}$ : [...] converti le pais e les vertus dont il estoit aornés et tuit des[...]trei $d[\ldots]$

Miniatúra: A képen szintén Jozafát és alattvalói láthatók, amint - vélhetően - egy pogány szentélyt semmisítenek meg (a kép középső része elmosódott).

A $126^{v}$ foliumon található miniatúra teljes egészében megsemmisült (szándékosan kivakarhatták), a francia címsornak pedig csupán elenyésző töredéke olvasható ki:

f. 126v: [...] Barlaam e cil li ensegna

Elképzelhető, hogy a miniatúrán hasonló jelenet szerepelt, mint ami a BnF Gr. 1128-as kézirat $189^{v}$ foliumán látható: a kép Jozafát találkozását ábrázolja egy szerzetessel, aki elvezeti ôt mesteréhez, Barlámhoz.

A fentiek alapján a következő megállapításokat tehetjük. Az Iviron 463 jelzetü kézirat illusztrátora (aki egyben másolója is volt) minden bizonnyal a Barlám-regény korábban kialakult ikonográfiai hagyományát követte a miniatúrák elkészítésekor. Erre utal számos párhuzam a BnF Gr. 1128-as kódex és az ivironi kézirat illusztrációi között ${ }^{18}$

${ }^{18}$ Az elemzés során csupán néhány, a tanulmány szempontjából fontos egyezést jelöltem. Az említett példákon kívül azonban több más esetben is megtaláljuk az ivironi miniatúrák megfelelőjét a párizsi kéziratban. 
(a Barlám-regény illusztrációs hagyományának megismeréséhez elsősorban a párizsi kézirat adhat támpontokat, ugyanis az ismert kéziratok közül ez tartalmazza a legtöbb és legjobb állapotban fennmaradt miniatúrákat), jóllehet a két kézirat között filiációs kapcsolat nem mutatható ki. (A párizsi kézirat a regényes szentélet hosszú változatát tartalmazza, míg az ivironi kódex a rövid változatot őrizte meg, a két kódex a Robert Volk által összeállított genealógiai ábrán két különálló ághoz tartozik.) ${ }^{19} \mathrm{~A}$ párhuzam a miniatúrák témaválasztásában, a képen ábrázolt jelenetek kompozíciós elvében (tárgyak és személyek hasonló elrendezése, színek és formák egyezése stb.), valamint a kép helyének kijelölt szöveghelyek egyezésében egyaránt megmutatkozik. Fontos ugyanakkor azt is megjegyezni, hogy a Barlám-regény esetében a szöveg és a szentélet képi megjelenítésének hagyománya mellett további elemmel is számolhatunk: számos kéziratban találunk címsorokat is, amelyek szintén egyfajta szöveghagyományt tükröznek. A Barlám-regény több illusztrált kéziratában találunk közvetlenül a képek mellett magyarázó feliratot, sőt, akad arra is példa, hogy az illusztráció megfestése ugyan elmaradt, képfeliratok mégis szerepelnek a kéziratban. A címek tehát a képek elkészítése előtt már a másoló számára ismertek voltak, ezeket a kézirat lapjaira még a miniatúrák megfestése előtt bemásolta. Úgy tűnik, ezen görög képcímhagyományhoz köthetők az ivironi kódex ófrancia szövegében olvasható piros tintával írt címsorok is. A görög címekkel való párhuzamokat tekintve valószínüsíthető, hogy az ófrancia nyelvű címsorok beillesztése nem a francia írnok „találmánya” volt. Feltételezésünk szerint az ismeretlen francia szerző, akárcsak a regény szövegét, a címsorokat is adott görög mintaszöveg alapján fordította. Erről tanúskodnak azon képcímek, amelyek mellett a kéziratban miniatúra nem található, valamint azon címek, amelyek a miniatúrán ábrázolt jelenethez kevéssé köthetők, ugyanakkor párhuzamba állíthatók más Barlám-kéziratban szereplő görög címsorral. További kérdéseket vetnek fel azon esetek, ahol a francia írnok látszólag „eltévelyedik": nem a megfelelő illusztráció mellé másolja be a címet, vagy a miniatúra egy-egy jelenetét másik kép mellett szereplő címben írja le. A fent tárgyalt jelenségek alapján feltételezhetjük, hogy egyes esetekben az ivironi kódex illusztrátora eltérhetett az adott mintától (a jelenség leginkább a fent részletesen tárgyalt $6^{\mathrm{r}}$ foliumon szereplő miniatúra kapcsán figyelhető meg). Az eredeti mintától való eltérés, a miniatúrán ábrázolt jelenet módosítása magyarázatul szolgálhat azon esetekre, amikor a képcím és a kép tartalma nem, vagy nem pontosan egyezik. Mindazonáltal fontos megjegyezni, hogy mivel viszonylag kevés illusztrált Barlám-kézirat maradt fenn (azok is sok esetben hiányos vagy megrongálódott állapotban), a kérdéssel kapcsolatban nem vonhatunk le biztos következtetéseket.

Mindezek alapján összességében hasonló következtetésre juthatunk, mint a kézirat görög és ófrancia szövegének összefüggései esetében (lásd bevezető): a görög másoló-illusztrátor és a francia fordító közös mintapéldánnyal dolgozhattak nem csupán az alapszöveg, de az illusztrációk és az azokhoz tartozó képcímek készítésekor is. Az általunk korábban is már feltételezett, mára elveszett mintapéldányban képek is szere-

${ }^{19}$ R. Volk: i. m. (6. jegyz.) VI/1. függelék. 
pelhettek, valamint a képekhez kötődően akár címsorok is, amelyeket a francia fordító a föszöveggel együtt, szintén a görög minta alapján fordított. Kérdés ugyanakkor, hogy ha mindketten - a görög másoló és a francia fordító is - egyazon mintapéldányt használták, vajon a görög szövegbe a címsorok miért nem kerültek végül be. További kérdés lehet, vajon a kódexlapok mely részére kerültek volna a címsorok. A magyarázó feliratokat tartalmazó Barlám-kéziratokban egyaránt találunk arra példát, hogy a címsor a szövegen belül, illetve a margón szerepel. ${ }^{20} \mathrm{Az}$ ivironi kézirat esetében további támpontot adhat ugyanakkor a Vat. Gr. 394 jelzetű kézirat, amely feltételezhetően ugyanannak a másolónak (Kónstantinos) a munkája, miként az ivironi kódex is. A vatikáni kézirat kizárólag görög nyelvű szöveget, Ióannés Klimakos („Lépcsős” Szent János) A Paradicsom lépcsője (Scala Paradisi) címü művének másolatát tartalmazza. A két kézirat - az ivironi és a vatikáni kódex - nem csupán tulajdonságait tekintve hasonló, de méretre is megegyezhetett ${ }^{21}$ (a formátum egyezésére csupán következtetni lehet, ugyanis míg a vatikáni kódex szinte kifogástalan állapotban maradt fenn, az ivironi kézirat a többszöri lapszél levágások miatt ma már jelentősen kisebb méretü), a vatikáni kódex ugyanúgy tartalmaz illusztrációkat, arany majuszkulákat, és a margó mérete is azonos lehetett a két kéziratban. A vatikáni kéziratban találunk piros tintás képfeliratokat is, amelyek legtöbbször a margón, illetve egyes esetekben közvetlenül a miniatúrán szerepelnek, valamint a kézirat lapszéleit több helyütt scholion tölti ki. Anélkül, hogy további feltételezésekbe bocsátkoznánk, annyit megjegyezhetünk, hogy az ivironi kézirat esetében is az tűnik valószínűbbnek, hogy ha terveztek oda címeket, azok a margóra kerültek volna, amelyet azonban a kézirat jelen állapotában a francia kézírás teljességgel kitölt. E tekintetben helytálló következtetéseket csupán abban az esetben vonhatnánk le, amennyiben pontos adataink lennének azzal kapcsolatban, hogy a kézirat különféle rétegei (görög szöveg, arannyal megfestett görög majuszkulák, miniatúrák, miniatúrák piros kerete, ófrancia fordítás, piros tintás ófrancia címsorok) mely sorrendben kerültek a kódex lapjaira. Ugyan korábbi tanulmányomban már felhívtam a figyelmet arra a jelenségre, hogy néhány esetben úgy tünik, az aranyszínű görög majuszkula a francia kézírás felett szerepel, ${ }^{22}$ tehát vélhetően a fordítás bemásolása után festették meg, valamint a miniatúrákat szegélyező piros képkeret esetében sem mindenütt egyértelmű, hogy a francia szöveg alatta vagy felette helyezkedik el, biztosabb megállapításokat csupán a kézirat autopsziája révén tehetnénk.

\footnotetext{
20 A kéziratok leírását lásd Toumpouri: i. m. (1. jegyz.) Barlaam and Ioasaph 167-168.

${ }^{21}$ D’Aiuto: i. m. (2. jegyz.) 31.

${ }^{22}$ Egedi-Kovács: i. m. (4. jegyz.) A Barlám és Jozafát regény kétnyelvű változata 79.
} 


\title{
SUMMARY
}

The study examines the relations between different aspects (Ancient Greek main text, miniatures, Old French translation on the margins, Old French headlines) of the manuscript Iviron № 463, which is a bilingual (Ancient Greek-Old French) Byzantine manuscript kept on Mount Athos, from a new perspective by including formerly not investigated viewpoints: by exploring the relationship between the miniatures and the headlines that are highlighted by red ink in the Old French text. The study also mentions the explanatory inscriptions in codices that preserved the Greek versions of the Barlaam-romance and are relevant in connection with the Iviron manuscript, furthermore, it investigates the common features of the manuscripts. The analysis reveals new important relations regarding the circumstances of the creation of codex Iviron.

Keywords: cod. Athon. Iviron 463, Barlaam and Josaphat, hagiography, Vat. gr. 394, BnF gr. 1128, King's College Library, cod. 45, miniatures, explanatory inscriptions

\author{
EGEDI-KOVÁCS EMESE \\ ELTE Eötvös József Collegium \\ Byzantium Központ \\ egedi-kovacs@caesar.elte.hu
}

A cikk a Creative Commons Attribution 4.0 International License (https://creativecommons.org/ licenses/by/4.0) feltételei szerint publikált Open Access közlemény, melynek szellemében a cikk bármilyen médiumban szabadon felhasználható, megosztható és újraközölhető, feltéve, hogy az eredeti szerző és a közlés helye, illetve a CC License linkje és az esetlegesen végrehajtott módosítások feltüntetésre kerülnek. (SID_1) 